ume reduction surgery in an animal model of emphysema. $\mathbf{J}$ Thorac Cardiovasc Surg 1999;117:728-35.

2. Weder W, Thurnheer R, Stammberger U, Burge M, Russi EW, Bloch KE. Radiologic emphysema morphology is associated with outcome after lung volume reduction. Ann Thorac Surg 1997;64:313-20.

3. Ferguson MK, Reeder LB, Mick R. Optimizing selection of patients for major lung resection. J Thorac Cardiovasc Surg 1995; 109:275-83.

4. Carlin JI, Hsia CCW, Cassidy SS, Ramanathan M, Crifford PS, Johnson RL. Recruitment of lung diffusing capacity with exercise before and after pneumonectomy in dogs. J Appl Physiol 1991; 70:135-42.

5. Johnson RL, Hsia CCW. Functional recruitment of pulmonary capillary. J Appl Physiol 1994;76:1405-7.

6. Takeda S, Wu EY, Epstein RH, Estrera AS, Hsia CCW. In vivo assessment of changes in air and tissue volumes after pneumonectomy. J Appl Physiol 1997;82:1340-48.

12/8/101927

\section{Pulmonary surfactant and cardiopulmonary bypass in infants}

To the Editor:

We read with interest the recent article by Paul and colleagues ${ }^{1}$ describing changes in pulmonary surfactant after cardiopulmonary bypass (CPB) in a group of infants having surgery for congenital heart disease.

In this article the authors report concentrations of phospholipid and, indirectly, protein in returned fluid from tracheal lavage. There is no apparent attempt to correct concentrations for variable recovery of epithelial lining fluid in these specimens. To define the concentration of surfactant components in sampled secretions, a marker of dilution should be used, allowing the result to be expressed as concentration in epithelial lining fluid. ${ }^{2}$ Results expressed as concentrations in raw lavage fluid are impossible to interpret meaningfully.

Paul and colleagues do report the phospholipid/protein ratio of tracheal lavage specimens. This ratio does nothing to clarify the data and certainly cannot be interpreted as an attempt to correct for dilution, given their later statement that alveolar protein concentration is known to be increased after CPB. A useful marker of dilution of epithelial lining fluid must not be present in increased concentration in the damaged lung. For this reason protein (along with albumin and sphingomyelin) is not suitable in this population. ${ }^{3}$

Paul and colleagues report a significant fall in total phospholipid concentration immediately after CPB. In their discussion they state: "Our data support the findings of McGowan and colleagues, who demonstrated an alteration in surfactant composition in older infants and children after CPB." In fact, these findings are at odds with those of McGowan and colleagues, ${ }^{4}$ who found no difference in total phosphatidylcholine recovered by bronchoalveolar lavage before and after CPB. In the other published study looking at phospholipid after CPB in children, LeVine and colleagues ${ }^{5}$ showed no difference in phosphatidylcholine levels between a group of children who had undergone CPB and a control group. Both of these studies involved greater numbers of patients having CPB than in that of Paul and colleagues, and both are also subject to the same criticism of not appropriately correcting results for dilution.

There may well be significant abnormalities of pulmonary surfactant that contribute to postoperative lung dysfunction in this patient population. McGowan and colleagues ${ }^{4}$ did find a change in the proportion of phospholipid in pulmonary surfactant subtypes after CPB (a measurement not influenced by dilution of specimens), which would have important functional implications. This subject warrants further investigation, but care must be taken to express findings in a way that will add to our understanding of the consequences of CPB on the composition and function of pulmonary surfactant.

Kenneth John Millar, MRCP, FRACP

Peter Anderson Dargaville, FRACP

Michael South, MD, FRACP

Intensive Care Unit

Department of Neonatology

Royal Children's Hospital

Flemington $R d$

Parkville, Victoria 3052

Melbourne, Australia

\section{REFERENCES}

1. Paul DA, Greenspan JS, Davis DA, Russo P, Antunes MJ. The role of cardiopulmonary bypass and surfactant in pulmonary decompensation after surgery for congenital heart disease. J Thorac Cardiovasc Surg 1999;117:1025-6.

2. Reynolds HY. Bronchoalveolar lavage [review]. Am Rev Respir Dis 1987;135:250-63.

3. Dargaville PA, South M, Vervaart P, McDougall PN. Validity of markers of dilution in small volume lung lavage. Am J Respir Crit Care Med. In press.

4. McGowan FX Jr, Ikegami M, del Nido PJ, et al. Cardiopulmonary bypass significantly reduces surfactant activity in children. J Thorac Cardiovasc Surg 1993;106:968-77.

5. LeVine AM, Lotze A, Stanley S, et al. Surfactant content in children with inflammatory lung disease [see comments]. Crit Care Med 1996;24:1062-7.

$12 / 8 / 102476$

\section{Reply to the Editor:}

We thank Millar and colleagues for their interest in our article, "The Role of Cardiopulmonary Bypass and Surfactant in Pulmonary Decompensation after Surgery for Congenital Heart Disease." ${ }^{1}$ We concur that our data have certain limitations and must be interpreted with a degree of caution. Although we did not account for the variable recovery of epithelial lining fluid by using a marker of dilution, we made every effort to standardize the timing and technique of the lavage fluid with each procedure. Although a measurement of dilution may have been helpful, even this method has potential limitations ${ }^{2}$ and, as mentioned in the letter, our method is similar to that used in other studies in children undergoing bypass for congenital heart disease. ${ }^{3,4}$ Millar and colleagues also pointed out the potential limitations to using total protein as the denominator. However, as stated in our conclusions, we 